\title{
Dugdale モデルを用いた下限界応力拡大係数筑囲の解析
}

\author{
福村直樹 ${ }^{* 1}$, 佐々木大輔 ${ }^{* 2}$, 濱田繁 ${ }^{* 3}$, 野口博司 ${ }^{* 4}$
Threshold Stress Intensity Factor Range Analysis Using Dugdale Model

\author{
Naoki FUKUMURA ${ }^{* 5}$, Daisuke SASAKI, \\ Shigeru HAMADA and Hiroshi NOGUCHI
}

${ }^{5}$ Department of Mechanical Engineering, Faculty of Engineering, Kyushu University, Moto-oka 744, Nishi-ku, Fukuoka-shi, Fukuoka, 819-0395 Japan

\begin{abstract}
An evaluatuation for threshold stress intensity factor range under a stress controlled condition, using effective threshold stress intensity factor range, was proposed. Threshold stress intensity factor range was evaluated by analyses of plasticity-induced crack closure for two types of crack size:a small crack and a long crack. Plasticity-induced crack closure was analyzed for two dimensional crack in plane stress. Besides, theoretical examinations were performed in order to explain the mechanism that the fatigue limit of high hardness steel decrease with a rise of hardness. Relationship between threshold stress intensity factor range and pre-crack length which was evaluated by analysis of plasticity-induced crack agreed with experimental results qualitatively. Dependency of yield stress was different between a small crack and a long crack. The threshold stress intensity factor range of a long crack decrease with a rise of yield stress. This result could be helpful to reveal the mechanism that the fatigue limit decrease with a rise of hardness in high hardness.
\end{abstract}

Key Words : Fatigue, Stress Intensity Factor, Crack Closure, Crack Propagation, Dugdale model Numerical Simulation

\section{1. 粕言}

一般的に下限界応力拡大係数範囲 $\Delta K_{\text {th }}$ の測定には $\Delta K$ 漸减試験が用いられる. しかし, 疲労限度は荷重履 歴に依存するため， $\Delta K_{\mathrm{th}}$ は条件によって多様に変化す ることが予想される，そこで宮崎ら ${ }^{(1)}$ は実用部材の疲 労強度設計を念頭に, 応力制御下におけるき裂材のき 裂停留限界を定量的に評価する值として， $\Delta K_{\text {th }}$ を提案 している.図1に宮崎らによる $\Delta K_{\text {th }}$ とき裂寸法 $\sqrt{\text { area }}$ の 関係を示した模式図を示す.ここで $\Delta K_{\text {th }}$ がき裂寸法に 依存するき裂を短いき裂，き裂が十分長く $\Delta K_{\text {th }}$ がき裂 寸法に依存しないき裂を長いき裂と定義する．この $\Delta K_{\mathrm{th}}$ と $\sqrt{\text { area }}$ の関係を力学的に検証するため, 疲労き 裂閉口現象に注目し解析的研究を行う. 疲労き裂閉口 現象のメカニズムには塑性誘起, 酸化物誘起, 破面粗

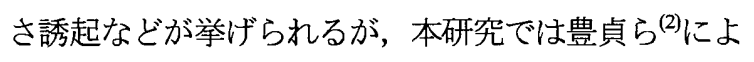

\footnotetext{
${ }^{* 1}$ 学生員, 九州大学大学院工学府（† 819-0395 福岡県福 岡市西区元岡 744)

${ }^{2} 2$ 正員, 九州大学大学院工学府

*3正員, 九州大学大学院工学研究院

* フェロー, 九州大学大学院工学研究院

E-mail: n.fukumura16@kyudai.jp
}

る塑性誘起き裂閉口解析モデルを応用して検討を行う. 一方，疲労限度は硬さがある程度大きくなると硬さ に対し低下する報告がなされている(3).一般に硬さと 引張強さや降伏応力は相関があるので, 引張強度や降 伏応力についても同傾向があると思われる. 報告の中 では原因について材料が欠陷に対して敏感になるため と解釈しているが，著者らは塑性誘起き裂閉口に起因 して疲労限度が硬さに対して低下するものと考え，任 意のき裂長さをもつ金属材料の，応力制御下における 疲労き裂停留限度に及ぼす降伏応力の影響について検 討する.

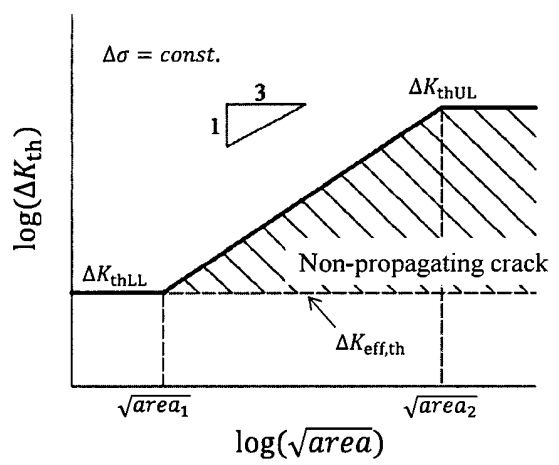

Fig.1 Relationship between $\Delta K_{\mathrm{th}}$ and $\sqrt{\text { area }}$. ${ }^{\text {(1) }}$ 
以上のことを踏まえ，本研究では下限界応力拡大係 数範囲 $\Delta K_{\mathrm{t}}$ について解析的な評価を行うことを目的と して，豊貞らによる塑性誘起き裂閉口解析を応用して $\Delta K_{\text {th }}$ を解析的に求める. 次いで $\Delta K_{\mathrm{th}}$ の初期き裂長さ・ 降伏応力依存性について検討を行う。

\section{2. 解析方法}

本研究では均質等方性材料の無限板中に存在する二 次元き裂を対象とし，平面応力条件下において遠方か ら一様な繰返し応力を受ける疲労き裂伝ぱに伴うき裂 開閉口挙動の解析を行う．材料は弾完全塑性体を仮定 し，き裂先端の塑性域に対し Dugdale 型の結合力モデ ルを採用する. 材料定数は維弾性係数 $E=206 \mathrm{GPa}$ ，ポ アソン比 $v=0.3$, 応力比は $R=0$, 降伏応力 $\sigma_{\mathrm{Y}}=294$ $\mathrm{MPa}$ とした.

\section{$2 \cdot 1$ 解析モデル}

図 2 に解析モデルの模式図を示す.このモデルでは Newman のき裂閉口解析モデル(4) と同様に, き裂前方の 塑性域を $n$ 個の棒要素に分割し，き裂伝ぱに伴いき裂 先端前方の棒要素がき裂先端後方に残留するとした. 無限板における Dugdale モデル(5)では，き裂半長 $c$ のき 裂におけるき裂中央からの塑性域先端位置は, 最大外 応力を $\sigma_{\max }$ として次式で与えられる.

$$
a=c \cdot \sec \left(\frac{\pi \cdot \sigma_{\max }}{2 \sigma_{\mathrm{Y}}}\right)
$$

Dugdale モデルにおける仮想き裂部に棒要素を $n$ 個配 置すると，一様外応力 $\sigma_{\infty}$ が作用した際のき裂中央から の位置 $x_{j}$ における開口変位 $V\left(x_{j}\right)$ は次式のようになる.

$$
V\left(x_{j}\right)=\sigma_{\infty} \cdot f\left(x_{j}\right)-\sum_{j=1}^{n} \sigma_{i} \cdot g\left(b_{i}, x_{j}\right)
$$

ここで, $f\left(x_{j}\right)$ : 単位外応力による $j$ 番目要素の開口変位, $g\left(x_{j}\right)$ : 単位内部态力による $j$ 番目要素の開口変位である. き裂中央側から $j$ 番目の棒要素に応力 $\sigma_{j}$ が作用したと すると, 棒要素のゲージ長さ $L\left(x_{j}\right)$ と開口変位 $V\left(x_{j}\right)$ の関 係は次のように表される.

$$
V\left(x_{j}\right)=L_{j}\left(1+\frac{\sigma_{j}}{E}\right)
$$

また, き裂開口応力 $\sigma_{\mathrm{op}}$ は実き裂先端後方一つ目に配置

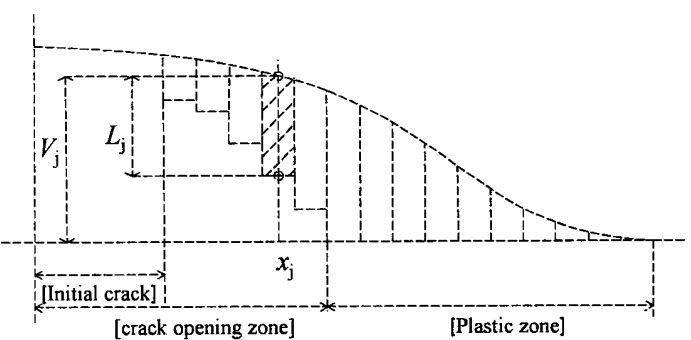

Fig.2 Schematic illustration of plasticity-induced crack closure model.
されている棒要素が分離し始めるとき，すなわち棒要 素に作用する応力が 0 のときの一様外応力とした. そ して得られたき裂開口応力 $\sigma_{\mathrm{op}}$ より，以下のように $\Delta K_{\text {eff }}$ を計算した。

$$
\left.K_{\text {cAt }} \quad q_{\max }-q_{\mathrm{p}}\right) \sqrt{\pi \cdot c}
$$

き裂を進めるタイミングとしては最小荷重時とした。

\section{$2 \cdot 2$ き翌停留条件}

図 3 にき裂を $1 \mathrm{~mm}$ から伝ぱさせた場合の, 式(4)に よって得られたき裂伝ぱに伴う $\Delta K_{\mathrm{eff}}$ の推移を示す．忘 力制御下において疲労き裂が伝ぱし始めると，塑性誘 起き裂閉口により開口応力 $\sigma_{\mathrm{op}}$ が上昇するため $\Delta K_{\mathrm{eff}}$ が 低下しその後 $\Delta K_{\mathrm{eff}}$ は極小值をとる. この極小值が後に 述べる $\Delta K_{\text {efft }}$ より小さくなると疲労き裂は停留する.

ここで $\Delta K_{\text {effith }}$ の物理的意味を考慮すると，疲労き裂は 除荷過程においてき裂先端で逆塑性域が形成されなけ れば伝ぱできずに停留すると考えられる.つまり，除 荷過程に执いて転位が射出されない条件より停留条件 は，転位が射出される限界の応力拡大係数 $K_{\mathrm{e}}$ を用いて 以下のように表すことができる.

$\Delta K_{\text {eff,th }}=2 K_{\mathrm{e}}$

したがって, 下限界有効応力拡大係数範囲 $\Delta K_{\text {effit }}$ は材 料定数であり，き裂長さによらず一定值をとる．鉄鋼 の場合， $\Delta K_{\text {effi, }}=3.0 \mathrm{MPa} \cdot \mathrm{m}^{1 / 2}$ 程度()である. そこで今 回は鉄鋼材料を想定し $\Delta K_{\mathrm{effith}}=3.0 \mathrm{MPa} \cdot \mathrm{m}^{1 / 2}$ とした.

\section{3. 解析結果および考察}

\section{$3 \cdot 1$ 初期き裂長さについて}

図 4 に前章で示した方法によって得られた $\Delta K_{\text {th }}$ と初 期き裂長さの関係を示す. 図 4 において停留き裂が存 在する領域は初期き裂長さによって二つの領域に分け られる。一つ目は小規模降伏条件を十分満たし $\Delta K_{\text {th }}$ が 初期き裂長さに依存せず一定となる長いき裂の領域, 二つ目は $\Delta K_{\text {th }}$ が初期き裂長さに依存する短いき裂の領 域である. 短いき裂の領域では初期き裂長さの増加に

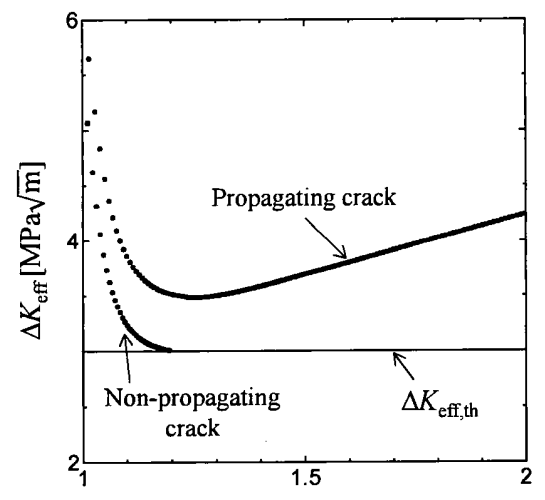

Crack length $c[\mathrm{~mm}]$

Fig.3 Change of $\Delta K_{\text {eff }}$ with crack propagation. 
伴い $\Delta K_{\mathrm{t}}$ の值が増吹し，初期き裂長さが $1 \mathrm{~mm}$ を越えたあた りから徐々に飽和していく傾向を示す。この傾向は実験結 果(の)定性的に一致する. しかし，短いき裂領域での $\Delta K_{\text {th }}$ をよく近似しているとされる村上の式(7と比較してみると， 村上の式では傾きが $1 / 3$ であるのに対し，今回の解析の結果 では1/3より若干小さい傾きを示した。

\section{3-2 降伏志力依肎性}

次に図 4 に示した関係における降伏忘力依存性を調べる ための解析を行った. 結果を図 5 に示す. 短いき裂の領域 では $\Delta K_{\mathrm{th}}$ の值は降伏灾力の堌加に伴い上昇する. 一方, 長 いき裂の領域では降伏応力が増吋ると $\Delta K_{\mathrm{t}}$ の值は减少し ている.

疲労き裂の停留はき裂長さの増吅によるき裂進展駆動力 の増加と，塑性誘起き裂閉口によるき裂隹展抵抗の増加の 相対関係によって成り立つ非定常現象であるため, $\Delta K_{\mathrm{th}}$ は 多様に変化することが想像できる. き裂先端こおいて形成 される塑性域の寸法は降伏応力に反比例して小さくなる. 長いき裂の領域では小規模降伏条件を满足しており，塑性 域寸法が小さくなると塑性誘起き裂閉口の影響が減少しき 裂面を閉口しようとする応力が減少する.したがって，き 裂面は降伏态力の増吹に伴、開きや打くなり疲労き裂は停 留しにくくなるため， $\Delta K_{\text {th }}$ の值力゙低下したものと考えられ る.一方短いき裂の領域では村上の式わによって経験的に良 く表される傾向と同一の傾向を示しているが，具体的なメ カニズムについては今後検討を要する. また，降伏応力が 増吋すとき裂長さに対して塑性域が小さくなり，小規模 降伏を満たしやすくなるため短いき裂と長いき裂の閾值は き裂の短、側に移行していることがわかる. 以上の結果か ら得られた知見を整理すると図 6 のような関係が分かる。

図 6 に示した関係を考慮すると $\Delta K_{\text {th }}$ か硬度や降伏㐫力に対 して低下する現象を説明できると考えられる.

以上のように，硬さや降伏応力が高く，一見疲労特性に 優れていると思われるような材料に対しても，き裂長さに よってその優位性が崩れる可能性があると考えられる.

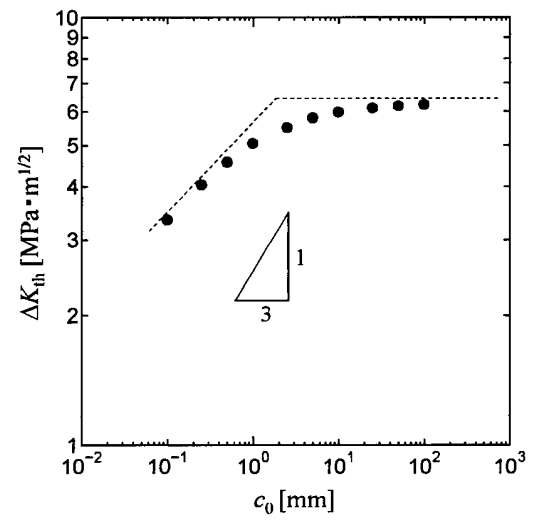

Fig.4 Relationship between threshold stress intensity factor range $\Delta K_{\text {th }}$ and initial crack length $c_{0}$.

\section{4. 結}

塑性誘起き裂閉口に注目し Dugdale モデルを応用した塑 性誘起き裂閉口解析モデルを用いて下限界㐫力拡大係数範 囲 $\Delta K_{\mathrm{th}}$ の初期き裂長さ，降伏忘力依存性について解析的検 討を行った. その結果, 塑性誘起き裂閉口解析によって求 めた $\Delta K_{\text {th }}$ の值は，村上らの結果と定性的に一致し，また。 $\Delta K_{\mathrm{t} 1}$ の降伏心力の依存性についも説明が可能であること が示された.

\section{文献}

(1) Miyazaki, T., et al, Trans. Jpn. Soc. Mech. Eng. Series A,Vol.68, No.673, (2002) pp.68-72.

(2) Toyosada, M., et al, Int J Fatigue, Vol.26, No9, 2004, pp983-992.

(3) M.F. Garwood, Interpretation of Tests and Correlation with Service, ASM(1951) pp.1-77.

(4) Newman,Jr.J.C., ASTM STP 748, (1981), 53-84.

(5) Dugdale, D.S., J. Mech. Phys. Solids, 8(1960), pp. 100-104.

(6) Liaw, P.K. et al, Acta Metal., Vol.31, No.10(1983), pp.1581-1587.

(7) Murakami, Y., Metal Fatigue:Effect of small crack and Nonmetalic Inclusions (2002), pp1-72, Elsevier.

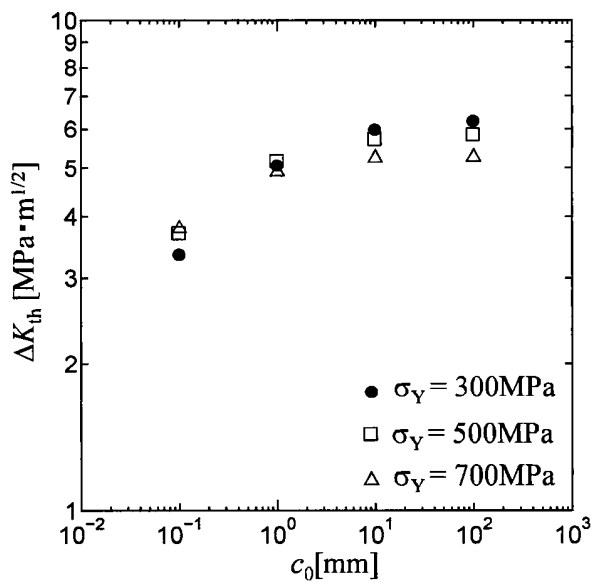

Fig.5 Relation between threshold stress intensity factor range $\Delta K_{\text {th }}$ and yield stress $\sigma_{\mathrm{Y}}$.

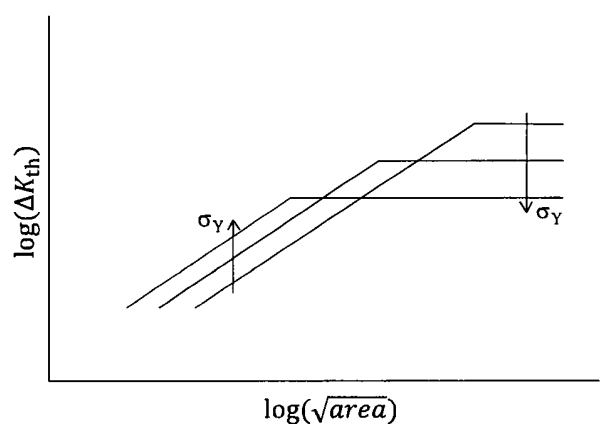

Fig.6 Effect of yield stress on $\Delta K_{\mathrm{th}}$. 